\title{
PENGARUH INTERAKSI TOTAL QUALITY MANAGEMENT DAN SISTEM PENGHARGAANTERHADAP KINERJA MANAJERIAL (Studi Empiris Pada Hotel di Kota Medan)
}

\author{
JADONGAN SIJABAT \\ Fakultas Ekonomi Universitas HKBP Nomensen Medan \\ jadongansidjabat@gmail.com
}

\begin{abstract}
ABSTRAK
Penelitian ini merupakan suatu studi mengenai system akuntansi manajemen. Penelitian ini bertujuan untuk menguji pengaruh TQM terhadap kinerja manajerial dengan system penghargaan sebagai variabel moderating. Penelitian ini dilakukan dengan mensurvei para manajer hotel berkuatitas tinggi di kota Medan. Unit analisisnya adalah para manajer hotel level menengah. Terdapat tujuh puluh tujuh kuesioner yang diterima, dan dianalisis dengan regresi sederhana dan interaksi perkalian. Hasil menunjukkan bahwa terdapat pengaruh langsung antara penerapan TQM terhadap kinerja manajerial. Hasil juga menunjukkan bahwa terdapat pengaruh interaktif antara TQM dan system penghargaan terhadap kinerja manajerial.
\end{abstract}

Kata kunci: Total Quality Management (TQM), SistemPenghargaan, KinerjaManajerial

\section{PENDAHULUAN}

Berlakunya Asean Free Trade Area (AFTA) menyebabkan perusahaan di setiap Negara khususnya di wilayah ASEAN dihadapkan pada situasi persaingan global.Persaingan global ini memberikan banyak pilihan kepada konsumen, dimana mereka semakin sadar biaya (cost conscious) dan sadar nilai (value conscious).

Salah satu pendekatan dalam menghadapi era globalisasi ialah dengan menerapkan konsep Total Quality management (TQM).TQM merupakan suatu sistem yang dapat dikembangkan menjadi pendekatan dalam menjalankan usaha untuk memaksimalkan daya saing organisasi melalui perbaikan terus menerus atas produk, jasa, tenaga kerja, proses dan lingkungannya (Tjiptono, 2001). Dalam meningkatkan kinerja, banyak perusahaan sering menggunakan teknik TQM.Selain itu, teknik TQM juga telah diakui dapat membantu meningkatkan kepuasan konsumen, kepuasan karyawan dan produktivitas (Wollner,2002).

Penggunakan teknik TQM dan sistem akuntansi manajemen secara interaktif yang mempengaruhi kinerja perusahaan menjadi salah satu topik yang menarik dalam riset riset yang telah dilakukan.Beberapa perusahaan yang menerapkan TQM telah berhasil meningkatkan kinerjanya, tetapi ada 
juga yang belum mampu meningkatkan kinerja mereka.Namun demikian sedikit sekali bukti empiris yang menguji alasan atau faktor-faktor penyebab ketidak-konsistenan hasil penerapan teknik TQM ini (Powel, 2005).

Fakta ini menunjukkan bahwa tidak ada sistem akuntansi manajemen secara universal selalu tepat untuk bisa diterapkan pada seluruh organisasi pada setiap keadaan.Namun sistem akuntansi manajemen tersebut tergantung juga pada faktor-faktor kondisional yang ada dalam organisasi yang bersangkutan. Beberapa peneliti bidang akuntansi menyatakan bahwa kinerja perusahaan yang rendah, disebabkan oleh ketergantungan terhadap sistem akuntansi manajemen perusahaan tersebut yang gagal dalam penentuan sasaran-sasaran yang tepat, ukuranukuran kinerja dan sistem penghargaan atau reward system(Kaplan,2000; Banker et.al.,2003).Peneliti lain yang melakukan pengujian untuk melihat faktor-faktor penyebab ketidakefektifan penerapan TQM menyatakan bahwa efektivitas penerapan TQM memerlukan perubahan mendasar pada infrastruktur organisasional meliputi: sistem alokasi wewenang pembuatan keputusan, sistem pengukuran kinerja, sistem penghargaan serta hukuman atau punishment(Wruck dan Jensen, 1994). Walau demikian temuan Ittner dan Larcker (1995) tidak menemukan bukti bahwa organisasi yang mempraktikkan TQM dan sistem akuntansi manajemen dapat mencapai kinerja yang tinggi.Penelitian lain menemukan adanya pengaruh interaktif (bersama-sama) antara praktik penerapan TQM dengan desain sistem akuntansi manajemen terhadap kinerja(Khim dan Larry, 1998; Retno,2010).

Banyak perusahaan dewasa ini dituntutoleh lingkungan ekonomi yang dihadapi untuk melakukan pengembangan terhadap praktik-praktik akuntansi manajemen yang inovatif dan relevan. Tekanan persaingan global akhir-akhir ini telah mengubah lingkungan ekonomi, yang memaksa banyak perusahaan di Amerika Serikat untuk mengubah secara dramatis cara mereka mengoperasikan bisnis. Terciptanya lingkungan baru pada akuntansi manajemen disebabkan oleh perubahan ini, setidak-tidaknya untuk sejumlahbesar organisasi, karena lingkungan berubah, maka akuntansi manajemen tradisional tidak digunakan lagi.

Sistem akuntansi manajemen kontemporer berkembang sebagai reaksi terhadap perubahan signifikan pada lingkungan bisnis yang dihadapi baik perusahaan jasa, maupun perusahaan manufaktur.Tujuan keseluruhan sistem akuntansi manajemen kontemporer adalah untuk meningkatkan kualitas,kepuasan, relevansi, dan dan penetapan waktu informasi biaya 
(Steven, 1993 dalam Mowen \& Hansen,2010).Praktek TQM dan/atau JIT yang efektif memerlukan perubahan dalam sistem akuntansi manajemen, komponen penting sistem akuntansi manajemen dalam perubahanperubahan ini antara lain adalah pengumpulan informasi baru, diseminasi informasi lintas hirarki organisasional dan perubahan sistem penghargaan, tujuan kinerja, ukuran kerja(Khim dan Larry, 2008).

Untuk merekonsiliasi hasil penelitian yang tidak konsisten tersebut memerlukan penelitian-penelitian lebih lanjut untuk mengetahui apakah interaksi praktik penerapan TQM dan sistem akuntansi manajemen berpengaruh terhadap kinerja.Itu sebabnya, penelitian ini kembali dilakukan untuk mendapatkan hasil terbaru tentang hal ini.

Penelitian sebelumnya yang telah dilakukan mengenai penerapan TQM,kebanyakan diperusahaan manufaktur.Masih sedikit penelitian yang dilakukan pada perusahaan jasa perhotelan. Pada persaingan global dimana terjadi perkembangan teknologi modern, deregulasi ekonomi dan pasar bebas sehingga tidak hanya perusahaan manufaktur, tetapi juga perusahaan jasa perlu melakukan peningkatan kualitas dan melakukan perbaikan yang terus menerus, khususnya perhotelan juga merupakan salah satu sektor usaha pendukung berkembangnya dan berhasilnya perekonomian suatu negara. Karakteristik unik produk hotel yang berorientasi pada masyarakat, pelayanan menurut selera pelanggan, perlunya hubungan langsung antara manajer dan karyawan dengan pelanggan. Karenanya kepuasan pelanggan merupakan faktor kunci kesuksesan sebuah hotel, maka dapat dikatakan semua hotel sangat menekankan pada high quality pelayanan pada pelanggan. Oleh karena itu, penelitian ini mencoba meneliti mengenai penerapan TQM pada perusahaan jasa perhotelan. Selanjutnya, adapun yang menjadi permasalahan pokok yang akan diteliti lebih lanjut dalam penelitian ini sebagi berikut :

1. Apakah penerapan TQM berpengaruh terhadap kinerja manajerialperusahaan jasa perhotelan ?

2. Apakah interaksi penerapan TQM dan sistem penghargaan berpengaruh terhadap kinerja manajerialperusahaan jasa perhotelan ?

\section{TELAAH TEORITIS}

\section{Konsep Total Quality Management}

Banyak defenisi mengenai Total Quality Management(TQM). Salah satunya sebagai mana yang dikemukakan oleh Nasution (2005). Nasution (2005) menjelaskan bahwa TQM merupakan suatu pendekatan 
dalam menjalankan usaha yang mencoba memaksimalkan daya saing organisasi melalui perbaikan terus-menerus atas produk, jasa, proses dan lingkungannya.

TQM lebih menekankan pada produk dan pelanggan (customer) bukan produksi massa. Karyawan bertanggung jawab pada peningkatan kemampuan pabrik dalam menyelenggarakan berbagai aktivitas, namun tanggung jawab untuk mendeteksi perubahan-perubahan yang tidak sesuai dengan departemen pengendalian kualitas merupakan wewenang personalia lini (Khim dan Larry, 2008).

Filosofi TQM membuat masing-masing karyawan bertanggung jawab untuk mengontrol kualitas dan menghentikan produksinya ketika terjadi masalah dalam pabrik(Monden, 1989 dalam Khim dan Larry, 2008). Karyawan didorong untuk mengidentifikasikan berbagai cara untuk memperbaiki kualitas produk dan proses (Siegel et al, 2007). Karenanya penting bagi para manajer untuk memberikan wewenang kepada karyawannya untuk ikut aktif dalam mengambil inisiatif dengan harapan keterlibatan karyawan tersebut dapat meningkatkan proses produksi (Ichniowski et al., 2017; Sarkar, 2007).

\section{Konsep TQM Pada Industri Hotel}

Tahun 1982 The American Hotel \& Motel Association (AH \& $M A) m e l a k u k a n$ penelitian mengenai status jaminan kualitas pada industri hotel dan motel Amerika.The American Hotel \& Motel Association (AH \& MA)membuat definisi kualitas adalah sebagai "peningkatan standar perorangan yang konsisten".Hall dan Collins mengartikan ungkapan ini dengan "...menetapkan, mengkomunikasikan dan mempertahankan standar saudara" (Deborah.B \& Priscilla.B, 2008).

Praktek-praktek SDM dalam organisasi TQM harus kongruen dengan iklim budaya yang dibangun diatas asumsi-asumsi bersama dedikasi karyawan dan manajemen pada kualitas dan kepuasan pelanggan.Ketika Top Manajemen memutuskan mengembangkan budaya TQM, tiap hotel bekerja untuk mengkomunikasikan misi baru itu ke seluruh organisasi.Pergantian budaya ke TQM meminta Top Manajemen untuk membagi semua informasi yang relevan pada karyawan. Walaupun hal ini kadang-kadang membuat takut orang yang menerima informasi, manajemen hotel-hotel TQM percaya bahwa komunikasi yang sering, jujur dan terbuka dengan para karyawan dibutuhkan untuk memperkuat budaya kualitas (Charles.G.P, 2006). 
Beberapa studi kasus manajemen kualitas pada era 1980-an mengalami kesuksesan, namun Walker dan Salameh (1990) dalam Deborah.B \& Priscilla.B (2008) hanya menemukan persentasi kecil dari hotel-hotel di AS dalam hal manajemen kualitas, kemudian melakukan penelitian mengenai kualitas di tahun 1990-an. Hotel-hotel yang telah memakai konsep manajemen kualitas dilaporkan operasi labanya dan kepuasan karyawannya meningkat secara statistik.

Penelitian Deborah. B \&Priscilla.B (2008) yang memasukan prinsip-prinsip orientasi proses, elemen manusia dan perspektif budaya kualitas dalam sistem manajemen, menunjukkan bahwa hotel-hotel ukuran kecil dan sedang lebih sedikit menerapkan TQM dari pada hotel-hotel besar. Temuan ini berlawanan dengan industri lain yaitu perusahaan ukuran kecil dan menengah lebih condong menaikan kualitas daripada kompetitor besar mereka.

\section{Kinerja Manajerial}

Performance(kinerja) adalah hasil kerja yang dapat dicapai oleh seorang atau sekelompok orang dalam suatu organisasi, sesuai dengan wewenang dan tanggung jawab masing-masing, dalam rangka upaya mencapai tujuan organisasi bersangkutan secara legal, tidak melanggar hukum dan sesuai dengan moral maupun etika(Suyadi, 2009). Menurut Mahoney, dkk (1963) dalam Nur Indriantoro (1993), yang dimaksud dengan kinerja manajerial adalah kinerja para individu anggota organisasi dalam kegiatan-kegiatan manajerial, antara lain: perencanaan, investigasi, koordinasi, supervisi, pengaturan staf (staffing), negosiasi dan representasi.Kinerja manajerial merupakan salah satu faktor yang dapat meningkatkan keefektifan organisasi.

\section{TQM dan Kinerja Manajerial}

Seseorang yang memegang posisi manajerial diharapkan mampu menghasilkan suatu kinerja manajerial. Berbeda dengan kinerja karyawan yang pada umumnya bersifat kongkrit, kinerja manajerial bersifat abstrak dan komplek. Manajer menghasilkan kinerja dengan mengarahkan bakat dan kemampuan, serta usaha beberapa orang lain yang berada di dalam daerah wewenangnya (Mulyadi dan Johny, 1998).

Tujuan perusahaan dalam menghasilkan produk berkualitas adalah tercapainya kepuasan pelanggan (customersatisfaction) yang ditandai dengan berkurangnya keluhandari para pelanggansehingga menunjukkan kinerja (performance)perusahaan yang meningkat. Dari penelitian Madu 
et. al (2005) menunjukkan bahwa ada hubungan antara konstruk kualitas dan kinerja organisasional. Untuk itu penting bagi perusahaan untuk memahami indikator-indikator kritis dalam dimensi kualitas yang mempengaruhi kinerja organisasi.

Tersziovski dan Samson (2009) yang meneliti mengenai elemenelemen TQM yang dijadikan sebagai sistem penghargaan kualitas.Mereka melakukan uji hubungan antara faktor elemen TQM yang dipilih terhadap faktor kinerja.Hasil penelitiannya menyimpulkan faktor elemen TQM mempengaruhi kinerja.

\section{Sistem Penghargaan (Reward System)}

Penghargaan (reward)dapat menarik perhatian karyawan dan memberi informasi atau mengingatkan mereka akan pentingnya sesuatu yang diberi reward dibandingkan dengan yang lain. Reward juga meningkatkan motivasi karyawan terhadap ukuran kinerja, sehingga membantu karyawan bagaimana mereka mengalokasikan waktu dan usaha mereka. Reward berbasis kinerja mendorong karyawan mengubah kecenderungan mereka dari semangat untuk memenuhi kepentingan diri sendiri ke semangat untuk memenuhi tujuan organisasi. Reward berbasis kinerja memberi dua manfaat: memberi informasi dan memberikan motivasi (Mulyadi dan Johny, 1998).

Reward adalah semua bentuk return baik finansial maupun non finasial yang diterima karyawan karena jasa yang disumbangkan ke perusahaan. Reward berupa finansial yaitu berbentuk gaji, upah, bonus, komisi, asuransi karyawan, bantuan sosial karyawan, tunjangan libur atau cuti tetap dibayar dan sebagainya. Reward berupa non finansial seperti tugas yang menarik, tantangan tugas, tanggung jawab tugas, peluang, pengakuan, pencapaian tujuan serta lingkungan pekerjaan yang menarik(Schuler dan Huber, 2006). Reward merupakan salah satu strategi manajemen sumber daya manusia untuk menciptakan keselarasan kerja antar staf dengan pimpinan perusahaan dalam mencapai tujuan dan sasaran yang sudah ditetapkan (Walker, 2002). Program reward sangat penting untuk mendapatkan perhatian yang sungguh-sungguh, karena reward dapat meningkatkan maupun menurunkan prestasi kerja, kepuasan kerja maupun motivasi karyawan (Handoko, 1997). 


\section{Interaksi TQM dan Sistem Penghargaan Terhadap Kinerja Manajerial}

Menurut Snell dan Dean (2002), sistem penghargaan (reward) yang lama (pemanufakturan tradisional) memberi gambaran tradisional karyawannya sebagai orang yang pasif, operator mesin yang tidak berpendidikan dan betul-betul terisolir.Sementara pada pemanufakturan TQM lebih berorientasi pada pemberdayaan karyawan, sehingga pendesainan sistem reward mungkin salah satu metode yang paling penting untuk mengurangi dan memperkuat perilaku yang diinginkan untuk keberhasilan penerapan TQM.Dengan demikian, karyawan yang mempunyai kontribusi atau memberikan informasi bermanfaat untuk peningkatan mutu seharusnya menerima penghargaan dari manajemen. Sementara teori pembanding yang ada dalam dalam hal bentuk penghargaan, bukti empiris menyatakan bahwa perusahaan telah mulai menerapkan outcome-based contingent pay bagi karyawan dengan menekanan karyawan untuk mencapai kinerjanya dihubungkan dengan sasaran-sasaran (Coopers dan Lybrand, 2002; Wruck dan Jensen, 2004; Mac Duffie 2005; Milgrom dan Roberts, 2005; Ichniowski et al, 2017).

Hasil penelitian Khim dan Larry (2008) menyatakan bahwa kinerja yang tinggi dapat dicapai jika praktek TQM digunakan bersama dengan program kinerja yang digunakan sebagai dasar pemberian atau reward performance contingent insentive plans. Ichniowski et al (2017) menyatakan bahwa kinerja yang tinggi pada dasarnya tergantung pada program pemberian reward jika dihubungkan dengan pekerjaan yang mendukung, meliputi penilaian kerja, informasi yang merata, dan keamanan kerja. Young et.al (2008) memperkirakan pengaruh independen dari insentif terhadap kinerja dengan TQM. Hasil temuan tersebut menunjukkan suatu pengaruh interaksi antara TQM dengan menggunakan rewardterhadap kinerja. Dengan demikian,pemberian reward merupakan pemotivasian yang lebih kuat bagi karyawan untuk meningkatkan kualitas kinerjanya. Berbeda dengan Deming (1992), gaji tetap ditambah dengan reward non keuangan merupakan cara yang terbaik untuk memotivasi karyawan dengan penerapan teknik TQM. Mac Duffie (2005) menyatakan bahwa bermacam-macam ketrampilan pemahaman konseptual yang dikembangkan karyawan pada produksi yang fleksibel akan sedikit digunakan kecuali bila karyawan termotivasi untuk memberikan mental sebaik upaya fisik. Dengan demikian karyawan akandiberikan kebebasan menentukan upaya-upaya untuk menyelesaikan masalah, hanya jika mereka yakin kepentingan individual mereka berhubungan dengan 
perusahaan dan bahwa perusahaan akan memberi timbal balik untuk kebaikan mereka. Menurut Young et.al (2008), kinerja dengan pemberianinsentif cenderung akan lebih tinggi dibandingkan dengan program pembayaran tetap. Temuanini memberikan dukungan pada aspek pemotivasian dan pembayaran insentif.

\section{Penelitian Sebelumnya}

Tabel 1. Rangkuman Hasil Penelitian Terdahulu

\begin{tabular}{|c|c|c|c|c|}
\hline No & $\underset{\text { tahun }}{\text { Peneliti \& }}$ & Variabel & $\begin{array}{c}\text { Alat analisis \& } \\
\text { sampel }\end{array}$ & Hasil Penelitian \\
\hline 1 & $\begin{array}{l}\text { Banker et.al } \\
(2003)\end{array}$ & $\begin{array}{l}\text { Ukuran } \\
\text { kinerja, } \\
\text { reward system } \\
\text { just-in-time, } \\
\text { teamwork dan } \\
\text { TQM. }\end{array}$ & $\begin{array}{l}\text { Analisis regresi } \\
\text { berganda } \\
\text { Sampel perusahaan } \\
\text { manufaktur }\end{array}$ & $\begin{array}{l}\text { Memberikan bukti empiris } \\
\text { bahwa frekuensi pelaporan } \\
\text { ukuran kinerja } \\
\text { manufakturing pada } \\
\text { karyawan terkait benar } \\
\text { dengan implementasi just- } \\
\text { in-time, teamwork dan } \\
\text { penerapan TQM. }\end{array}$ \\
\hline 2 & $\begin{array}{l}\text { Wruck dan } \\
\text { Jensen (2004) }\end{array}$ & $\begin{array}{l}\text { TQM, alokasi } \\
\text { hak } \\
\text { memutuskan, } \\
\text { sistem } \\
\text { pengukuran } \\
\text { kinerja, sistem } \\
\text { penghargaan } \\
\text { dan sanksi }\end{array}$ & $\begin{array}{l}\text { Analisis regresi } \\
\text { berganda } \\
\text { Sampel semua level } \\
\text { hirarki organisasional } \\
\text { perusahaan } \\
\text { manufaktur }\end{array}$ & $\begin{array}{l}\text { Implementasi efektif TQM } \\
\text { menghendaki perubahan } \\
\text { besar dalam infrastruktur } \\
\text { organisasional tertentu, } \\
\text { seperti pengalokasian hak- } \\
\text { hak memutuskan, sistem } \\
\text { reward dan sanksi. }\end{array}$ \\
\hline 3 & $\begin{array}{l}\text { Ittner \& } \\
\text { Larcker (2005) }\end{array}$ & $\begin{array}{l}\text { TQM, } \\
\text { informasi } \\
\text { baru, } \\
\text { informasi } \\
\text { lintas hirarki } \\
\text { organisasional } \\
\text { dan reward } \\
\text { system, kinerja } \\
\text { finansial dan } \\
\text { kinerja } \\
\text { kualitas }\end{array}$ & $\begin{array}{l}\text { Analisis regresi } \\
\text { berganda } \\
\text { Sampel semua level } \\
\text { hirarki organisasional } \\
\text { perusahaan } \\
\text { manufaktur }\end{array}$ & $\begin{array}{l}\text { Tidak menemukan bukti } \\
\text { bahwa organisasi yang } \\
\text { mempraktekan TQM dan } \\
\text { sistem akuntansi } \\
\text { manajemen yang meliputi } \\
\text { sasaran kinerja, sistem } \\
\text { ukuran kinerja \&reward } \\
\text { system, secara interaktif } \\
\text { dapat mencapai kinerja } \\
\text { financial dan kualitas yang } \\
\text { baik (tinggi). }\end{array}$ \\
\hline 4 & $\begin{array}{l}\text { Madu et. al } \\
(2005)\end{array}$ & $\begin{array}{l}\text { Kualitas, } \\
\text { kinerja } \\
\text { organisasional }\end{array}$ & $\begin{array}{l}\text { Analisis korelasi dan } \\
\text { regresi } \\
\text { Perusahaan } \\
\text { manufaktur }\end{array}$ & $\begin{array}{l}\text { Menunjukkan bahwa ada } \\
\text { hubungan antara konstruk } \\
\text { kualitas dan kinerja } \\
\text { organisasional. Untuk itu } \\
\text { penting bagi perusahaan }\end{array}$ \\
\hline
\end{tabular}




\begin{tabular}{|c|c|c|c|c|}
\hline & & & & \begin{tabular}{lr} 
untuk & \multicolumn{2}{c}{ memahami } \\
indikator-indikator & kritis \\
dalam dimensi kualitas \\
yang & mempengaruhi \\
kinerja organisasi.
\end{tabular} \\
\hline 5 & $\begin{array}{l}\text { Charles G. P. } \\
(2006)\end{array}$ & $\begin{array}{l}\text { Strategi SDM, } \\
\text { TQM }\end{array}$ & $\begin{array}{l}\text { Interview, analisis } \\
\text { diskriptif } \\
\text { Sampel } 9 \text { hotel }\end{array}$ & $\begin{array}{l}\text { Menunjukkan } 10 \text { strategi } \\
\text { SDM sebagai dukungan } \\
\text { TQM, strategi-strategi ini } \\
\text { memberikan kesempatan } \\
\text { pada profesional SDM } \\
\text { untuk mengevaluasi } \\
\text { kontribusi bagian mereka } \\
\text { sendiri. }\end{array}$ \\
\hline 6 & $\begin{array}{l}\text { Deborah. B \& } \\
\text { Priscilla. B } \\
(2008)\end{array}$ & TQM & $\begin{array}{l}\text { Chi Square pearson } \\
\text { Sampel : } 116 \text { hotel di } \\
\text { Amerika }\end{array}$ & $\begin{array}{l}\text { Hotel-hotel ukuran kecil } \\
\text { dan sedang lebih sedikit } \\
\text { menerapkan TQM dari } \\
\text { pada hotel-hotel besar, } \\
\text { temuan ini berlawanan } \\
\text { dengan industri lain yaitu } \\
\text { perusahaan ukuran kecil } \\
\text { dan menengah lebih } \\
\text { condong menaikan kualitas } \\
\text { daripada kompetitor besar } \\
\text { mereka. }\end{array}$ \\
\hline 7 & $\begin{array}{l}\text { Khim dan } \\
\text { Larry (2008) }\end{array}$ & $\begin{array}{l}\text { TQM, JIT, } \\
\text { tujuan kinerja, } \\
\text { sistem } \\
\text { pengukuran } \\
\text { kinerja, } \\
\text { reward } \\
\text { system, kinerja } \\
\text { pelanggan dan } \\
\text { kinerja } \\
\text { kualitas }\end{array}$ & $\begin{array}{l}\text { Analisis regresi } \\
\text { berganda } \\
\text { Sampel adalah } \\
\text { karyawan shopfloor } \\
83 \text { industri elektronik }\end{array}$ & $\begin{array}{l}\text { Ada pengaruh interaktif } \\
\text { antara pemanfakturan } \\
\text { TQM dan JIT dan sasaran } \\
\text { kinerja dan } \\
\text { penghargaan } \\
\text { terhadap kinerja. Tetapi } \\
\text { tidak ada pengaruh } \\
\text { interaktif } \\
\text { pemanfakturan TQM dan } \\
\text { JIT dan sistem pengukuran } \\
\text { kinerja terhadap kinerja. } \\
\text { Kinerja disini adalah } \\
\text { kinerja pelangggan dan } \\
\text { kinerja kualitas. }\end{array}$ \\
\hline 8 & $\begin{array}{l}\text { Tersziovski } \\
\text { dan Samson } \\
(2009)\end{array}$ & $\begin{array}{l}\text { TQM, kinerja } \\
\text { Variabel } \\
\text { kinerja dalam } \\
\text { penelitian ini } \\
\text { adalah } \\
\text { kepuasan } \\
\text { pelanggan, } \\
\text { moral pekerja, } \\
\text { produktuvitas, }\end{array}$ & $\begin{array}{l}\text { Analisis faktor, } \\
\text { regresi berganda } \\
\text { Perusahaan } \\
\text { manufaktur }\end{array}$ & $\begin{array}{lr}\text { Meneliti } & \text { mengenai } \\
\text { elemen-elemen TQM yang } \\
\text { dijadikan sebagai sistem } \\
\text { penghargaan kualitas, } \\
\text { melakukan test hubungan } \\
\text { antara faktor elemen TQM } \\
\text { yang dipilih terhadap } \\
\text { faktor } \\
\text { menyimpulkan kinerja, } \\
\text { faktor }\end{array}$ \\
\hline
\end{tabular}




\begin{tabular}{|c|c|c|c|c|}
\hline & & $\begin{array}{l}\text { kualitas output } \\
\text { dan } \\
\text { deliverinya. } \\
\text { Mereka }\end{array}$ & & $\begin{array}{l}\text { elemen TQM } \\
\text { mempengaruhi kinerja. }\end{array}$ \\
\hline 9 & $\begin{array}{l}\text { Retno } \\
\text { Kurnianingsih } \\
(2010)\end{array}$ & $\begin{array}{l}\text { Sistem ukuran } \\
\text { kinerja } \\
\text { \&reward } \\
\text { system kinerja } \\
\text { manajerial. }\end{array}$ & $\begin{array}{l}\text { Analisis regresi } \\
\text { berganda } \\
\text { Sampel : } 47 \\
\text { manajerial } \\
\text { perusahaan } \\
\text { manufaktur }\end{array}$ & 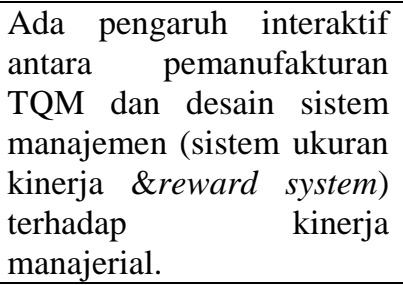 \\
\hline 10 & Mintje (2013) & $\begin{array}{l}\text { TQM, sistem } \\
\text { penghargaan, } \\
\text { sistem } \\
\text { pengukuran } \\
\text { kinerja, dan } \\
\text { kinerja } \\
\text { manajerial }\end{array}$ & $\begin{array}{l}\text { Analisis regresi } \\
\text { berganda } \\
\text { Sampel: } 43 \\
\text { Karyawan level } \\
\text { manajerial PT. Air } \\
\text { Manado }\end{array}$ & $\begin{array}{lr}\text { Ada pengaruh } & \text { sistem } \\
\text { penghargaan dan } & \text { sistem } \\
\text { pengukuran } & \text { kinerja } \\
\text { terhadap kinerja manajeral. } \\
\text { Namun, tidak terbukti } \\
\text { bahwa TQM berpengaruh } \\
\text { terhadap } \\
\text { manajerial. }\end{array}$ \\
\hline 11 & $\begin{array}{l}\text { Hernawan, dkk } \\
(2014)\end{array}$ & $\begin{array}{l}\text { TQM, sistem } \\
\text { penghargaan, } \\
\text { sistem } \\
\text { pengukuran } \\
\text { kinerja, dan } \\
\text { kinerja } \\
\text { manajerial }\end{array}$ & $\begin{array}{l}\text { Analisis regresi } \\
\text { berganda } \\
\text { Sampel: } 34 \text { Manajer } \\
\text { menengah PT. } \\
\text { Taspen (Persero) } \\
\text { Kantor Cabang } \\
\text { Semarang. }\end{array}$ & $\begin{array}{l}\text { TQM, sistem penghargaan, } \\
\text { dan sistem pengukran } \\
\text { kinerja baik secara parsial } \\
\text { maupun rimultan } \\
\text { berpengaruh r positif } \\
\text { signifikan terhadap kinerja } \\
\text { manajerial. }\end{array}$ \\
\hline
\end{tabular}

Sumber : Review Hasil-Hasil Penelitian , 2019

\section{Kerangka Pemikiran dan Hipotesis}

Tujuan perusahaan dalam menghasilkan produk berkualitas adalah tercapainya kepuasan pelanggan (customer satisfaction) yang ditandai dengan berkurangnya keluhan dari para pelanggansehingga menunjukkan kinerja (performance) perusahaan yang meningkat.Dari penelitian Madu et al.(2006) menunjukan bahwa ada hubungan antara konstruk kualitas dan kinerja organisasional.

Tersziovski dan Samson (2009) yang meneliti mengenai elemenelemen TQM yang dijadikan sebagai sistem penghargaan kualitas, melakukan test hubungan antara faktor elemen TQM yang dipilih terhadap faktor kinerja. Mereka menyimpulkan faktor elemen TQM mempengaruhi kinerja.

Berdasarkan penelitian Madu et al. (2006), dan Tersziofki dan Samson (2009) yang telah dikemukakan diatas, penelitian ini dimaksudkan 
menguji kembali pengaruh penerapan TQM terhadap kinerja menajerial yang dijelaskan dengan gambar 1 berikut :

Gambar 1. Model Pengaruh TQM Terhadap Kinerja Manajerial

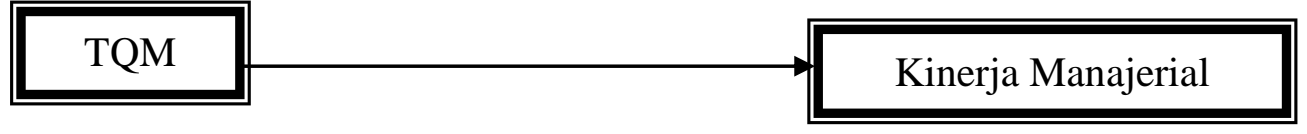

\section{H1:Penerapan TQM berpengaruh positif terhadap kinerja manajerial}

Sistem akuntansi manajemen bisa berinteraksi dengan sistem produksi untuk menghasilkan kinerja yang lebih tinggi dibandingkan yang bisa dicapai oleh sistem produksi sendiri. Interaksi dalam penerapan TQM bersama frekuensi pelaporan ukuran kinerja pada para karyawan akan menghasilkan kinerja karyawan yang tinggi. Contohnya, jika suatu organisasi berkeinginan mencapai sedikitnya beberapa level target kinerja pelanggan atau kinerja kualitas dengan menerapkan strategi manufakturing JIT atau TQM, dengan harapan kinerja pelanggan atau kinerja kualitasnya menjadi lebih tinggi dan memberikan informasi ukuran kinerja pelanggan atau kualitas yang lebih sering bagi karyawan, sehingga karyawan bisa menggunakannya untuk memonitor dan meningkatkan kinerja mereka.

Gaji kinerja-kontinjen akan mendorong motivasi lebih tinggi dan kemudian mendorong kinerja lebih tinggi. Penelitian Young et al. (2008) menunjukkan bahwa kinerja dengan gaji insentif cenderung menjadi tinggi dibandingkan rencana gaji tetap, hasil penelitian ini merupakan dukungan aspek motivasional gaji insentif. Implementasi TQM atau JIT manakala dipadukan dengan reward kinerja-kontinjen harus mengarahkan pada kinerja manufakturing yang lebih tinggi dari pada yang dicapai TQM dan/atau JIT tersendiri.

Berdasarkan uraian diatas, maka model kerangka pemikiran yang diajukan dalam penelitian ini seperti pada gambar 2 sebagai berikut :

Gambar 2. Model Pengaruh Interaktif Antara TQM dan Sistem Penghargaan Terhadap Kinerja Manajerial

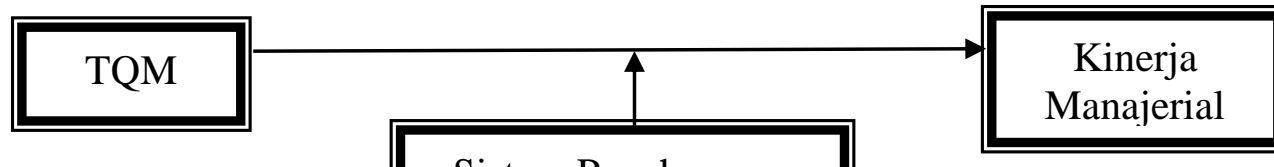

Sistem Penghargaan

H2: Interaksi antara penerapan TQM dan sistem penghargaan berpengaruh posistif terhadap kinerja manajerial 


\section{METODE PENELITIAN}

\section{Populasi dan Sampel}

Populasi dalam penelitian inimenggunakan manajer secara individual sebagai unit analisis.Responden yang digunakan adalah manajer tingkat menengah, dengan pertimbangan bahwa manajer tingkat menengah (1) merupakan pelaksanan keputusan manajemen puncak yang mampu berinteraksi dengan karyawan dan manajemen puncak, (2) biasanya terlibat langsung dengan kebijakan yang dilaksanakan oleh manajemen puncak.

Prosedur untuk pengambilan sampel dalam penelitian ini adalah purposive sampling.Sampel pada penelitian ini adalah para manajer yang bekerja di industri hotel berbintang 3,4 dan 5yang berada di Kota Medan.Dipilihnya kota Medan karena merupakan kota terbesar ke 3 di Indonesia yang merupakan salah satu destinasi terbaik Nusantara. Data penelitian dikumpulkan dengan mengirimkan kuesioner secara langsung.

\section{Definisi Operasional}

Total Quality Management (TQM) yang dimaksudkan dalam penelitian ini adalah suatu filosofi, suatu konsep dengan seperangkat prinsip-prinsip panduan yang merupakan dasar bagi suatu organisasi yang ingin secara terus menerus melakukan perbaikan dan penyempurnaan.Variabel TQM dalam penelitian ini diukur dengan memasukan elemen-elemen utama manajemen kualitas yaitu orientasi proses, elemen manusia, budaya kualitas, masing-masing item kuesioner ditulis secara khusus untuk industri hotel (disebut sebagai 12 prinsip manajemen yaitu: kepemimpinan, fokus pada customer, pemberdayaaan karyawan, perbaikan berkelanjutan, fakta dasar dalam pengambilan keputusan, pelatihan dan pengembangan, penghargaan (reward) dan pengakuan, fleksibelitas, peralatan dan teknik penggunaaanya, perencanaan strategi, tim kerja, dan keterlibatan pemasok.

Sistem penghargaan (reward system)yang dimaksudkan dalam penelitian ini adalah pemberian kompensasi pada manajer terdiri dari (1) pembayaran tetap saja, dan (2) pembayaran variabel yang jumlah ditentukan berdasarkan kinerja responden untuk memilih sistem kompensasi yang berlaku di hotel tempat mereka bekerja, kemudian mereka diminta menilainya. Variabel ini diukur dengan instrumen yang digunakan oleh Khim \& Larry dan dikembangkan oleh peneliti.

Kinerja manajerial yang dimaksud dalam penelitian ini adalah kinerja individu dalam kegiatan-kegiatan manajerial.Variabel kinerja 
manajerial diukur dengan menggunakan instrumen self rating yang dikembangkan Mahoney (1963) dalam Nur Indriantoro (1993).Dalam penelitian ini setiap responden diminta untuk mengukur sendiri kinerjanya dibandingkan dengan rata-rata kinerja rekan responden, dengan memilih skala satu sampai dengan sepuluh.Kinerja manajerial yang diukur meliputi delapan dimensi: perencanaan, investigasi, koordinasi, evaluasi, supervisi, negosiasi dan representasi serta satu dimensi pengukuran kinerja secara keseluruhan.

\section{Teknik Analisis}

Model regresi yang baik harus bebas dari asumsi klasik (multicollinearity dan heteroskedasticity).Oleh karena itu perlu dilakukan pengujian untuk mendeteksi ada atau tidaknya asumsi klasik tersebut.

Metode statistik yang digunakan untuk menguji hipotesis adalah regresi berganda (multiple regression) dengan bantuan perangkat lunak SPSS for windows versi 10. Metode yang menghubungkan satu variabel dependen dengan beberapa variable independen dalam satu model prediktif tunggal, sesuai dengan hipotesis yang diuji dalam penelitian ini, diadopsi dari model yang dikembangkan dalam penelitian Frucot dan Shearon (2001), Nur Indriantoro (1993), Bambang S (1998), dengan persamaan regresi sebagai berikut :

Dimana :

$$
\mathbf{Y}=\boldsymbol{\beta}_{\mathbf{0}}+\boldsymbol{\beta}_{1}+\boldsymbol{\beta}_{2}\left|\left(\mathbf{X}_{\mathrm{TQM}}-\mathbf{X}_{\mathrm{RWD}}\right)\right|+\mathbf{e}
$$

$$
\begin{array}{ll}
\mathrm{Y} & =\text { Kinerja Manajerial } \\
\mathrm{X}_{\mathrm{TQM}} & =\text { Total Quality Management } \\
\left|\left(\mathrm{X}_{\mathrm{TQM}}-\mathrm{X}_{\mathrm{RWD}}\right)\right| & =\text { Absolut interaksi } \mathrm{X}_{\mathrm{TQm}} \text { dan } \mathrm{X}_{\mathrm{RWD}} \\
\beta_{0} & =\text { Konstanta } \\
\beta_{1}-\beta_{2} & =\text { Koefisien regresi }
\end{array}
$$

\section{HASIL PENELITIAN DAN PEMBAHASAN}

\section{Gambaran Umum Responden}

Ringkasan pengiriman dan pengembalian kuisioner dalam penelitian ini ditunjukkan dalam tabel 2 berikut:

\section{Tabel 2. Rincian Pengiriman dan Penerimaan Kuesioner}

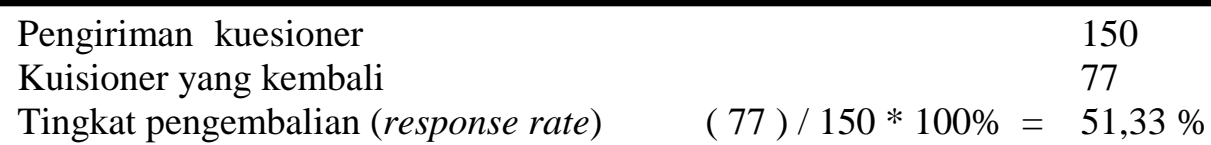


Kuisioner yang kembali, tetapi tidak dapat diolah

Sumber : Data primer diolah,2019

Profil responden dalam penelitian ini ditunjukkan dalam tabel 3 berikut.

Tabel 3.Profil Responden $(n=77)$

\begin{tabular}{|c|c|c|}
\hline & Jumlah & Persentase \\
\hline $\begin{array}{cc}\text { Gender } & \text { Perempuan } \\
& \text { Laki-laki }\end{array}$ & $\begin{array}{l}33 \\
44\end{array}$ & $\begin{array}{l}42,85 \\
57,14\end{array}$ \\
\hline $\begin{array}{ll}\text { Umur } & : 20-29 \\
& 30-39 \\
& >40\end{array}$ & $\begin{array}{c}8 \\
37 \\
32\end{array}$ & $\begin{array}{l}10,39 \\
48,05 \\
41,56\end{array}$ \\
\hline $\begin{aligned} \text { Pendidikan : } & \text { SMA } \\
& \text { Diploma/Sarjana Muda } \\
& \text { Sarjana (S1) } \\
& \text { Master }(\mathrm{S} 2)\end{aligned}$ & $\begin{array}{c}5 \\
25 \\
45 \\
2\end{array}$ & $\begin{array}{l}06,49 \\
32,47 \\
58,44 \\
02,59\end{array}$ \\
\hline $\begin{aligned} & \text { Masa kerja }:<5 \\
& 5-10 \\
&>10\end{aligned}$ & $\begin{array}{l}10 \\
31 \\
36\end{array}$ & $\begin{array}{l}12,98 \\
40,26 \\
46,75\end{array}$ \\
\hline
\end{tabular}

Sumber : Data primer diolah, 2019

\section{Uji Asumsi Klasik}

Uji multikolonieritas bertujuan untuk menguji apakah model regresi ditemukan adanya korelasi antar variable bebas (independen).Dari tabel 4 dan 5 dapat dilihat besaran korelasi antar varaiabel bebas yang mempunyai korelasi yang cukup tinggi, oleh karena korelasi ini masih dibawah $90 \%$, maka dapat dikatakan tidak terjadi multikolonieritas. Hasil perhitungan tolerance juga menunjukkan tidak ada variabel bebas yang memiliki nilai tolerance kurang dari 0,10 . Hasil perhitungan nilai variance inflaction factor (VIF) juga menunjukkan hal yang sama, tidak ada variabel bebas yang memiliki nilai VIF lebih dari 10 (Imam G, 2001). Jadi dapat disimpulkan tidak ada multikolonieritas antar variabel bebas dalam model regresi.

Tabel 4. Koefisien Korelasi Antar Variabel

\begin{tabular}{|c|c|c|}
\hline MODEL & TQM & REWARD \\
\hline TQM & 1,000 & $-0,070$ \\
\hline RWD & $-0,070$ & 1,000 \\
\hline
\end{tabular}


Tabel 5. Nilai Tolerance dan Variance Inflaction Factor (VIF)

\begin{tabular}{|c|c|c|}
\hline MODEL & TOLERANCE & VIF \\
\hline TQM & 0,898 & 1,115 \\
\hline RWD & 0,931 & 1,016 \\
\hline Dependent variable KM
\end{tabular}

Uji heteroskedastisitas untuk menguji apakah dalam model regresi terjadi ketidaksamaan varian dari residual satu pengamatan kepengamatan yang lain. Untuk mengetahui adanya kondisi heteroskedastisitas pada data penelitian ini maka digunakan uji Glejser yaitu dengan meregres nilai absolut residual terhadap variabel bebas (Gujarati, 1995), apabila variabel bebas signifikan secara statistik mempengaruhi variabel terikat, maka ada indikasi terjadi heteroskedatisitas, dengan persamaan regresi sebagai berikut :

$\mathrm{Absl}=\beta 0+\beta 1 \mathrm{TQM}+\beta 2 \mathrm{RWD}$ Tabel 6. Hasil Uji Heterokedastisitas (UJI GLEJSER)

\begin{tabular}{|l|c|c|}
\hline MODEL & Nilai $-\mathrm{t}$ & Probabilitas \\
\hline KONSTANTA & 0,130 & 0,885 \\
\hline TQM & 0,214 & 0,852 \\
\hline REWARD & 0,574 & 0,586 \\
\hline
\end{tabular}

Sumber :Data primer diolah, 2019

Dari tabel 6dapat dilihat bahwa tidak ada satupun variabel bebas yang signifikansecara statistik mempengaruhi variabel terikat nilai absolut (Absl).Hal ini terlihat dari probabilitas signifikasinya diatas tingkat kepercayaan $5 \%$,jadi dapat disimpulkantidak terdapat heteroskedastisitas.

\section{Pengujian Hipotesis}

Hasil analisis regresi berganda menunjukkan $R$ square sebesar 0,595 berarti $59,50 \%$ bisa dijelaskan oleh variable independen (TQM, RWD, dan interaksi TQM dengan RWD) sedangkan sisanya 40,50\% dijelaskan oleh variabel lain. Nilai $\mathrm{F}=21,92$, dengan tingkat signifikansi 0,000 . Karena probabilitas $(0,000)$ jauh lebih kecil dari 0,05 , maka model regresi dapat digunakan untuk memprediksi kinerja manajerial. 
Tabel 7. Hasil Analisis Regresi Berganda

UJI HIPOTESIS

\begin{tabular}{|l|c|c|c|}
\hline & Koefisien & Nilai $-\mathrm{t}$ & Probabilitas \\
\hline Konstanta $\left(\beta_{0}\right)$ & 61,309 & 60,48 & 0,000 \\
\hline TQM $\left(\beta_{1}\right)$ & 3,507 & 6,96 & 0,000 \\
\hline TQMRWD $\left(\beta_{2}\right)$ & 3,672 & 5,002 & 0,000 \\
\hline \multicolumn{2}{|r|}{$\mathrm{R}^{2}=0,595 ; \mathrm{F}=21,92 ; \mathrm{Sig}=0,000$} \\
\hline
\end{tabular}

Pengujian Hipotesis 1. Hipotesis 1 menyatakan bahwa penerapan Total Quality Management berpengaruh positif terhadap kinerja manajerial. Dari tabel 7 tampak bahwa TQM mempunyai pengaruh yang signifikan terhadap Kinerja manajerial ditunjukkan dengan $\mathrm{p}=0,000$ ( $<$ $0,05)$. Koefisien regresi positif, t-hitung $=6,96$, artinya bila penerapan TQM meningkat maka kinerja manjerial meningkat, demikian pula sebaliknya. Hal ini berarti hipotesis 1 diterima.

Pengujian Hipotesis2. Hipotesis 2 menyatakan interaksi Total Quality management dan sistem penghargaan (reward system)berpengaruh positif terhadap kinerja manajerial.Dari tabel 7 tampak nilai $\mathrm{t}$ - hitung sebesar 5,002 dengan probabilitas 0,000 lebih kecil dari 0,05. Hasil pengujian untuk melihat adanya pengaruh sistem penghargaan terhadap hubungan TQM dengan kinerja manajerial menghasilkan koefsien interaksi $\beta_{2}$ positif dan signifikan. Hal ini menunjukan bahwa hipotesis 2 diterima, artinya interaksi TQM dengan sistem penghargaa (reward system) mempengaruhi kinerja manajerial, ditunjukan dengan nilai $\beta_{2}=3,672$ dan probabilitas sebesar $0,000(\mathrm{p}<0,05)$.

\section{Pembahasan Terhadap Uji Hipotesis}

Hipotesis 1 yang menyatakan penerapan TQM berpengaruh terhadap kinerja dapat diterima ditunjukan dengan koefisien $\beta_{0}>0$ dan probabilitas 0,000 ( $\mathrm{p}<0,05)$. Hasil hipotesis ini mendukung penelitian yang dilakukan oleh Madu dan Kuei (1996) yang menyimpulkan adanya hubungan antara konstruk kualitas dan kinerja organisaional. Oleh karena itu penting bagi perusahaan untuk memahami indikator-indikator kritis dalam dimensi kualitas yang mempengaruhi kinerja organisasi. Hasil hipotesis ini juga mendukung Tersziovski dan Samson (2009) yang meneliti mengenai elemen-elemen TQM yang dijadikan sebagai sistem penghargaan kualitas,melakukan testhubungan antara faktor elemen TQM yang dipilih terhadap faktor kinerja. Mereka menyimpulkan faktor elemen TQM mempengaruhi kinerja. 
Kesuksesan penerapan TQM sangat dipengaruhi oleh keterlibatan dan komitmen CEO dan para manajer dalam pelaksanaan TQM tersebut, artinya kebijaksanaan aplikasi sistem TQM secara mendasar ditentukan dalam ruang rapat direksi (boardroom). Dengan keterlibatan penuh, rasa tanggung jawab manajer disini maka tentunya akan berpengaruh pada meningkatnya kinerja manajerial.

Hipotesis 2 yang menyatakan bahwa interaksi penerapan TQM dengan sistem penghargaan (reward system) berpengaruh positif terhadap kinerja manajerial dapat diterima, hal ini dibuktikan dengan koefisien interaksi $\beta_{2}>0$ dan probabilitas signifikan $(\mathrm{p}<0,05)$. Hasil hipotesis ini mendukung penelitian yang dilakukan oleh Khim \&larry (2008), serta temuan Retno (2010), mereka menemukan adanya pengaruh positif antara interaktifpemanufakturan TQM dan reward system terhadap kinerja. Dukungan hipotesis 2 ini selaras dengan yang dikemukakan oleh Mulyadi \& Johny (1998),rewarddapat menarik perhatian karyawan dan memberi informasi atau mengingatkan mereka akan pentingnya sesuatu yang diberi reward dibandingkan dengan yang lain.Reward juga meningkatkan motivasi karyawan terhadap ukuran kinerja, sehingga membantu karyawan bagaimana mereka mengalokasikan waktu dan usaha mereka. Reward berbasis kinerja mendorong karyawan mengubah kecenderungan mereka dari semangat untuk memenuhi kepentingan diri sendiri ke semangat untuk memenuhi tujuan organisasi. Reward berbasis kinerja memberi dua manfaat yaitu memberi informasi dan memberikan motivasi.

\section{PENUTUP}

\section{Kesimpulan}

Hasil analisis data dalam penelitian ini menunjukkan bahwa pengujian hipotesis 1 dan hipotesis 2diterima.Hipotesis 1 yang menyatakanpenerapan TQM berpengaruh positif terhadap kinerja dapat diterima.Hasil hipotesis ini mendukung penelitian yang dilakukan oleh Madu et al. (2006) yang menyimpulkan adanya hubungan antara konstruk kualitas dan kinerja organisaional.Hasil hipotesis ini juga mendukung Tersziovski dan Samson (2009) yang meneliti mengenai elemen-elemen TQM yang dijadikan sebagai sistem penghargaan kualitas, yang melakukan uji hubungan antara faktor elemen TQM yang dipilih terhadap faktor kinerja. Mereka menyimpulkan faktor elemen TQM mempengaruhi kinerja.

Hipotesis 2 yang menyatakan bahwa interaksi penerapan TQM dengan sistem penghargaanberpengaruh positif terhadap kinerja manajerial 
dapat diterima. Hasil hipotesis ini mendukung penelitian yang dilakukan oleh Khim \&larry (2008), serta temuan Retno (2010), mereka menemukan adanya pengaruh positif antara interaktif pemanufakturan TQM dan sistem penghargaan (reward system) terhadap kinerja.Dukungan hipotesis ini selaras dengan yang dikemukakan oleh Mulyadi dan Johny (2008),rewarddapat menarik perhatian karyawan dan memberi informasi atau mengingatkan mereka akan pentingnya sesuatu yang diberi reward dibandingkan dengan yang lain, rewardjuga meningkatkan motivasi karyawan terhadap ukuran kinerja, sehingga membantu karyawan bagaimana mereka mengalokasikan waktu dan usaha mereka. Reward berbasis kinerja mendorong karyawan mengubah kecenderungan mereka dari semangat untuk memenuhi kepentingan diri sendiri ke semangat untuk memenuhi tujuan organisasi. Reward berbasis kinerja memberi dua manfaat yaitu memberi informasi dan memberikan motivasi.

\section{Keterbatasan}

Penelitian ini memiliki keterbatasan-keterbatasan yang kemungkinan dapat menimbulkan gangguan terhadap hasil penelitian.Data yang dianalisis dalam penelitian ini menggunakan instrumen yang mendasarkan pada persepsi jawaban responden. Hal ini akan menimbulkan masalah jika persepsi responden berbeda dengan keadaan sesungguhnya. Penelitian ini hanya menerapkan metode survei kuisioner, peneliti tidak melakukan wawancara atau terlibat langsung dalam akitivitas perusahaan, sehingga kesimpulan yang diambil hanya berdasarkan pada data yang dikumpulkan melalui penggunaan instrumen secara tertulis.Kelemahan pendekatan survei umumnya terletak pada internal validity.Seperti yang telah dikemukakan sebelumnya, penggunaaan intrumen pengukuran kinerja manajerial self-rating cenderung menimbulkan leniency bias.

\section{DAFTAR PUSTAKA}

Bambang, S. 1998.'Pengaruh Struktur dan Kultur organisasional Terhadap Keefektifan Anggaran Partisipatif Dalam Peningkatan Kinerja Manajerial : Studi Empiris Pada Perusahaan Manufaktur Indonesia". Kelola, No 18/VII.P. 61-84.

Banker, R., G. Potter, and R. Schroeder.2003. "Exporting Manufacturing Performance Measures to Worker: An Empirical Study". Journal of Management Accounting Research: P. 33-35.

Charles.G.P. 2006. "Human-Resources Practices Of Hotels". Cornel Hotel \& Restourant Administration Quarterly (CHR).Vol.37. Iss 5 Oktober 1996. P.67 - 77 . 
Cooper \& Lybrand.2002. "Compensation Planning for 1993". New York, NY: Cooper and Lybrand.

Deborah.B \& Priscilla.B.2008. "TQM in American Hotels".Cornel Hotel \& Restourant Administration Quarterly (CHR).Vol.39. Iss 1 Februari 1998. P.26-33.

Deming, W.E. 1992. "Quality, Productivity, and Competitive Position". Cambridge, MA:MIT, Center for Advanced Engineering Study.

Frucot,V dan Shearon, W.T. 2001, Budgetary Partisipation, Locus of Control, anf Mexican Mangerial Performance and Job satisfaction, The Accounting Review, January, P.80-89.

Gujarati, D. 1995. Basic Econometrics.3rd ed. International Edition. Mc Graw - Hill.

Handoko, T.H., 1997, Manajemen Personalia dan Sumber daya Manusia, Ad.II, BPFE, Yogyakarta.

Hernawan, dkk, 2014, Pengaruh Total Quality Management (TQM), Sistem Pengukuran Kinerja dan Sistem Penghargaan Terhadap Kinerja Manajerial.Accounting Analysis Journal.Vol.3, No 1.Hal. 80 - 89.

Ichniowski, C.,K, Shaw and G. Prennushi. 2017. "The Effects of Human Resources Management Practice an Productivity: A Study of Steel Finishing Lines". The American Economic Review 87: P. 291-314.

Imam Ghozali. 2001. Aplikasi Analisis multivariate Dengan Program SPSS. Badan Penerbit Universitas Diponegoro.

Itter.C., and D.F. Larcker. 2005. "Total quality management and the choice of information and reward systems". Journal of Accounting Research (supplement): P. 1-34.

Kaplan,2000."Measures for Manufacturing Excellence". Boston, MA: Harvard Business School Press.

Khim Ling Sim and larry N. Killough. 2008. "The Performance Effects of Complementarities Between Manufacturing Practice and Management Accounting System". Journal of Management Accounting Research 10: P. 325-346.

MacDuffie, J.P. 2005. "Human Resources Bundles and Manufacturing Performance: organizational logic and Flexible Production Systems in the Word Auto Industry". Industrial and Labour Relations Review 48: P. 197-221.

Madu C.N, Kuei C.H\& Jaco R.A, 2005.“ A Comparative Analysis of Quality Practice in Manufacturing Firm in the U.S and Taiwan”. Decision science vol. 26 (5).Sepr-Okt.P.621-635.

Milgrom, P., and J. Roberts, 2000."The Economics of Modern Manufacturing Technology, Strategy, and Organization," The American Economic Review June. P. 511-528.

Mintje, Nastiti. 2013. "Pengaruh TQM, Sistem Penghargaan dan Sistem Pengukuran Kinerja Terhadap Kinerja Manajerial Pada PT. Air Manado, Jurnal EMBA, Vol.1, No. 3, September, Hal. $52-63$.

Mowen, Maryanne M., Hansen, Don R.. 2010. "Management Accounting". International Thomson Pubblising. P. 434-457. 
Mulyadi \& Johny Setyawan, 1998 "Sistem Perencanaan dan Pengendalian Manajemen", Universitas Gadjah Mada. Hal.213-214.

Nasution, M.N. (2005), Manajemen Mutu Terpadu. Ghalia Indonesia, Bogor.

Nur Indriantoro. 1993, "The Effect of Participative Budgeting on Job Perfomance and Job Satisfaction with Locus of Control and Cultural Dimensions as Moderating Variables," Ph.D. Dissertation, University of Kentucky, Lexington.

Powell, T.C. 2005. "Total Quality Management and Competitive advantage: A review and Empirical Study". Strategic Management Journal 16: P. 15-37.

Retno Kurnianingsih. 2010. "Pengaruh Sistem Pengukuran Kinerja dan Sistem Penghargaan Terhadap Keefektifan Penerapan Teknik Total Quality Management : Studi Empiris Pada Perusahaan Manufaktur di Indonesia" Simposium Nasional Akuntansi.

Sarkar, R.G. 2007."Modern Manufacturing Practices; Information, incentives and Implementation".Working Paper, Harvard Business School.

Siegel, D.S, D.A Waldman, W.E. Young dahl. 2007. "The Adoption of Advanced Manufacturing Technologies: Human Resources Management Implications". IEEE Transactions on Engineering Management 44; P. 288298.

Schuler, R.S. and Huber, V.I., 2006."Personnel and Human Resource Management". $5^{\text {th }}$ ed. USA: West Publishing Company.

Snell, S., and J. Dean.2002. "Integrated Manufacturing and Human Resources Management: A Human Capital Perspective". Academy of Management Journal 35: P. 467-504.

Suyadi Prawirosentono. 2009. "Kebijakan Kinerja Karyawan" BPFE Yogyakrta. h.2

Terziovski Mile, Samson Danny. 2009. "The Relationship Beetween Total Quality Management Practices and Operational Performance" Journal of Operation Management 17. P. 393 - 409.

Tjiptono, Fandi (2001), Prinsip-Prinsip Total Quality Mangement, andi Offset, Yogyakarta.

Walker, J.W., 2002. "Human Resource Strategy, New York: McGraw-Hill”. Inc. P. 323-324.

Wruck, K.H., and M.C. Jensen.2004. "Science, Specific Knowledge and Total Quality Management".Journal of Accounting and Economics: P. 247-287.

Wollner, GE. 2002. "The Law of Producing Quality". Quality Progress.

Young, S.M., M. Shields, and G. Wolf.2008. "Manufacturing Control and Performance: An Experiment". Accounting, Organization and Society 13 . P. 607-618. 